\title{
EFFECT OF MESOPOTAMIAN CIVILIZATIONS ON THE RELIGIONS OF ARABS BEFORE ISLAM
}

\author{
Hadeel Ghaleb Abbas \\ University of Baghdad
}

\begin{abstract}
Worship, beliefs and various religious rituals gained a significant place in the lives of Arabs since the period of the civilizations of Mesopotamia. Then, pre-Islamic Arabs had the same importance as they adopted these beliefs. The religions of pre-Islamic Arabs are mainly derived from the texts of ancient civilizations in the Mesopotamia valley (Babylonian, Assyrian, Sumerian, Akkadian, etc.). With their multiple dialects, these texts do not agree about various religious matters, as a result of the variation in the characteristics of these civilizations in terms of religious belief and worship, such as prayers, religious supplications, material eucharistic sacrifices. The current research attempts to find out how the religions of Mesopotamian civilizations affected pre-Islamic Arabs. Most of the religions belong to their ancestors in the period of ancient civilizations, especially Mesopotamian.
\end{abstract}

Keywords: Mesopotamia civilizations; religions; Pre-Islamic Arabs.

DOI: https//doi.org/10.3176/tr.2021.1.03

Received 9 April 2020, accepted 17 June 2020, printed and available online 10 March 2021

\section{Introduction}

Pre-Islamic Arabs, like the rest of the other peoples, worshiped the gods, and they believed that there were supreme powers, which in turn governed them and served as the authority over them. They also tried to approach them and work to placate them with their various means and methods, identified them with names and characteristics. In addition, they addressed them with their tongues and hearts, and 
made offerings. They took a series of paths that are what we call today religions (Hassan 2008: 162).

The religions of pre-Islamic Arabs are mainly derived from the texts of ancient civilizations in the Mesopotamia valley (Babylonian, Assyrian, Sumerian, Akkadian, etc.) with their multiple dialects. These are texts, none of which is agreed upon in various religious matters. This is due to the variation in the characteristics of these civilizations in terms of religious belief and worship, such as prayers, religious supplications and material sacrifices. These ancient texts also contained the names of a group of divinities and thanks to them the pre-Islamic Arab names of all deities and the type of benefit they wanted Baqer (2011: 24).

The pre-Islamic Arabs became famous as they practiced many religions, joined the pagan worship of planets, stars and fire, as well as other religions such as Judaism and Christianity. Some pre-Islamic Arabs sanctified a group of animals and worshiped them to obtain blessings. They named their children with animal names such as birds, aquatic animals and predators, or plants, as well as the names of parts of natural phenomena or land, and the Arabs inherited these names from their ancestors through ancient times (Ali 2001: 54).

Pre-Islamic Arabs worshiped the idols and monuments they inherited from ancient civilizations. Where these idols were distinguished in a variety of forms, including those in the form of humans, animals, or birds. Among the most famous of its names were "wad, saa ', yaghut, obstructing, eagle, lattat, al-izzah, minaa, hebel ... etc" (Kovalev 2000: 96).

Senior historians state that these religions have moved to the Arabian Peninsula, the countries of Yemen and Morocco as a result of the migration of most of the ancient Arab tribes from different countries to the Mesopotamia Valley. This is because of the many wars or desertification; the Mesopotamian civilizations had abundant fresh water, suitable for agriculture and animal husbandry. This leads to the adoption of the religions of the Mesopotamia at the time, and it was then transferred through them to other countries (Sarton 1955: 173).

\section{Concept of civilization}

Each society is characterized by important elements, and the first of these factors comes from the fact that the human being of a civilization believes in a strong idea or belief that will elevate him to the spirit world. It does not stop him from taking an interest in the worldly life; rather, he goes on trying to build civilization and rebuild the universe in response to this doctrine. Also, an individual's attempt to adhere to an identity stemming from this belief or idea is considered one of the most important factors that contribute to an individual's contribution to building the civilization to which he belongs, is proud of, and seeks to spread its principles to the whole world (Bin Al-Hassan 2015: 9).

Therefore, civilization has been defined linguistically as a word that was derived from the triple root of the word Hadar (Badawi 2005: 12). He mentioned (Al-Isfahani, 
$1385 \mathrm{AH}$ ) that it is a reflective word for the meaning of the Bedouins (Al-Asfahani 1956: 396). It also means the process of social, scientific, and literary advancement in urban areas (Al-Sayeh 1977: 66). Plus it is a term that is a phenomenon that bears many developments, which led to the variation of its definitions, purposes and concepts (Schweitzer 1963: 24). Also, it has been defined as a system and a social and cultural environment or way of life whose individuals tend to apply it according to the prevailing social laws and customs (Al-Saqri 2014: 33). Al-Sayeh (1977) indicated that it is "a group of human endeavors to think, invent and discover in nature with a view to achieving a better life, and civilization is all human activities associated with different aspects, whether worldly, religious, spiritual, material or mental" (Al-Sayeh 1977: 68).

\section{Mesopotamian religions}

The religious beliefs and practices of the Mesopotamian civilizations (the Sumerians, the Eastern Semitic Acadians, the Assyrians, the Babylonians, the Arameans, and the Chaldeans) were characterized by plural religions, i.e. people worshiped and believed in more than one deity (Rashid 2012: 7). Very little is known today about the religions of the tribes of Mesopotamia in prehistoric times, and most of it is uncertain and incomplete, because our information about it is based on the material left by a human being of caves, huts and mountain shelters where people used to live. Among the most important of these are statues, graves, spells, cartoons, reliefs, instruments, tools, and animal bones. We also do not have documents and transcripts about religious ideas, beliefs and practices, because writing was not known at the time (Saeed 1985: 101).

It is believed that the religions of Mesopotamia had a great influence on subsequent religions of all ages all over the world.

Historical studies indicate that idolatry can be seen as the first religion practiced in Mesopotamian valley. It was distinguished as a polytheistic religion, and this is what led to the presence of more than one deity, with different types and gender. It was divided into divinities of the male gender, and female-type divinities, as female idol worship was acceptable. Moreover, these acts of worship were monotheistic for some worshipers who believed that gods of specific type and form were superior to the rest. These worshipers often came from certain cities or small civilian states, because they saw these idols and idols as a person protecting them from the dangers of life (Sachs 1969: 610).

Some residents of Mesopotamia also worshiped nature and strength inherent in it, especially such phenomena as the sun, the flower Ishtar, and the rest of the other planets. Also, they worshiped the rain and the accompanying winds, thunder and lightning, and these phenomena and assets had gods called by names according to the variance and multiplicity of cities of that period (Suleiman 1992: 253).

Also, a group of tribes in Mesopotamia adopted the Jewish religion. Evidence for this is the important historical information contained in the Torah about Mesopotamia. 
As the Jewish religion from Mesopotamia took over a lot of legends, stories, poetry and knowledge, and included them in their Torah since the beginning of creation, therefore we can observe that Babylonian religious thought has been translated in the texts of the Torah. It thus became evident that the city of Babylon would have an influence on Judaism. All of this was the result of the Jews' fondness for emulating pagan religions (Jaafar 2017: 157).

Also, a few tribes from the Mesopotamia valley practiced Christianity. Thomas, who is one of the twelve disciples, is the first to preach this religion in Mesopotamia, as (Mar Mary), who is considered a student (Mar Adi), spread Christianity in Mesopotamia, specifically Babylon, Assyria, Armenia, Karkoukh Saluk (Kirkuk) and elsewhere in the first century. It is clear here that 'Hadeeb' (now Erbil) has played an important role in the history of the early Christian religion in the Mesopotamia valley (Habib 2012: 8).

There were multiple divinities in the Mesopotamia valley, and a complexity of the economic, social, political and religious life at the time. However, laws and regulations had been introduced to manage the existing relationships between people and for administrative and political dealings between peoples and their wise men. Historical studies confirm that the Mesopotamian civilization attained an advanced position, as they were not primitive, wild and marginal civilizations. The proof of this is the scientific, literary and political developments it has created. Its religious beliefs automatically imposed on them the need to obey 'God, King, Law, and Social Order'. They also learned from it many inherent values, such as honesty, compassion, affection, and help, and kept away the behavior of sedition and hostility to others, and behavioral disorders that destroy social relations. Thus, those civilizations were already considered the main and clear platform for the religion of later ages (Parpola 2004: 132).

This is confirmed by the Russian scientist Alsumaria (Kramer) ${ }^{1}$ in his book titled "History begins with Sumer", in which he says:

"The Sumerians cling to law and order, justice and freedom, uprightness and openness, mercy and compassion, and they abhor evil and lies, chaos and turmoil" (Akef 2009: 5).

\section{Religious beliefs of pre-Islamic Arabs}

Prior to Islam, the Arabian Peninsula region witnessed the spread of various and varied religious beliefs, most of which were an extension of the ideas of ancient primitive civilizations, especially the Mesopotamian civilization. The others were related to the rule of neighboring tribes of other peoples, as well as commercial contacts, and those beliefs imposed by automatic conditions such as conditions of war (Saeed 2007: 58).

${ }^{1}$ Samuel Noah Kramer, born in (1897) in the city of Kiev, considered one of the leading figures in the world for Near Eastern studies and professor of antiquities for the civilizations of Mesopotamia. Kramer tried to decipher some cuneiform writings dating back to the late Bronze Age around 1300 $\mathrm{BC}, \mathrm{He}$ also played a role in the publication and repair of Sumerian monuments, and also translated many reliable Sumerian texts, he died in 1990. 
Religious beliefs among Arabs before Islam, like ancient civilizations, were not based on a single belief system, such as the systems of heavenly Christian and Jewish religions. Rather, there was a group of scattered religious ideas that were not connected by a single thread, that is, the religious beliefs of Arabs before Islam were an extension of primitive beliefs based on the worship of what the ancestors worshiped, who worshiped plants, animals, idols, idols, natural phenomena and even man himself (Kharroub 2005: 6).

Arabs before Islam used to worship any god they believed to be a descendant of their ancestors. Therefore, they owe him loyalty and respect, submission, and appreciation, so if that god is a plant they refrain from eating it, and if god is an animal they do not kill it, but they announce mourning for it if they find it dead (Suleiman 1992: 226).

Before Islam, the Arabs were affected by the religion of what was called Animism, which means believing the existence of 'divine spirits' that possess the extraordinary ability to influence people's lives in good and evil. As a result, before Islam, the Arabs resorted to embodying these souls in certain forms, as they were designed in the form of a tree, or as stones of varying sizes and types (Saeed 2007: 61).

Among the other things that characterized the Arabs before Islam, is the emergence of the so-called polytheism, which means the multiplicity of gods. Each tribe had its own god to protect it from any evil, especially the attack of enemies. Therefore, they believed that the tribes should keep their gods in goodness. In the event of their loss in the war, the defeated sometimes resorted to worshiping other deities, as the former ones were weak and not able to defend them. The dominant people may also be influenced by the worshipers of the conquered ones, who were subjected to them, adding the gods of the conquered to their gods, especially if the conquered were highly cultured (Ali 2001: 72).

Some historical studies indicate that the practice of pagan beliefs did not spread without many Arabs embracing heavenly religions. Christianity entered the Arabian Peninsula primarily from Iraq, and then the Levant through traders and missionaries. Christianity at that time was concentrated in small, scattered tribes, but it also spread in large kingdoms such as the kingdom of Bani Lakhm in the east in Al-Hirah, and Ghassanids in the west on the borders of the Byzantine state, in addition to Najran in the south (Kharroub 2005: 8).

As for Judaism, it was characterized by its limited spread, because of the nature of the religion itself. It namely lacks the nature of evangelization that is present in Christian religion, and this has led to lack of interest in spreading the faith (Saeed 2007: 77).

Ajinah (2005) confirms that religious beliefs of ancient civilizations first appeared as a myth, i.e. the part that is spoken in rituals as the heritage material that was formulated during the first human stages. Thought thus mixed with imagination. Therefore, the myth is a natural extension of belief, as it works to clarify it, enrich it, and establish it in formulation to preserve and circulate it between generations (Ajinah 2005: 74).

What reached the Arabs before Islam from the practice of religious beliefs, is a 
proof that the Arab nation adopted from the era of ancient civilizations, especially the civilization of Mesopotamia. An indication of the importance of the historical religious thought for the Arabs before Islam, is what came to us from some of the codifications related to that era (Baqer 2011: 65).

\section{The effect of Mesopotamian religions on pre-Islamic Arabs}

Worship and beliefs and various religious rites have acquired a large and important space in the lives of Arabs since the era of the civilizations of Mesopotamia. All ancient human civilizations knew their religions and left a written and architectural heritage full of religious beliefs and myths. As psychologist Carl Jung ${ }^{2}$ asserts, "the feeling of the sacred in the past is an inner feeling closely related to human being, and therefore it is not extinct" (Jung 1988: 23).

The Arab society before Islam, like other peoples, had perceptions and questions about the manifestations of nature, divine powers, life and death, so all these contents formed what is called religious beliefs. Herodotus ${ }^{3}$ mentioned in his history: "There are no people who are more religious than the Arabs before Islam, or they are the most powerful and immensely worshiping nations in worship. They have jurisprudence, Sunnah and Sharia in performing rituals, opinions, beliefs, wide imagination and spiritual attachment" (Herodotus 2001: 328).

It is well known to us that each civilization has its own circumstances and data that are different from the previous and the subsequent, but that does not mean that there are no common denominators among them in terms of ideas, beliefs, customs and traditions. Nor does it deny that there are conclusions and ideals that people have extracted in present times from previous times, and they are certainly successful experiences. Therefore, subsequent peoples, especially Arabs before Islam, focused on the positive aspects of it. They have thus found many benefits from them in their present, and taking into account the historical contexts in those past ages, including the generous historical lessons that they have become part of their present, especially in their practice of religious beliefs (Muhammad 1970: 23)

The religions of Mesopotamia are among the most influential religions among the religious beliefs of pre-Islamic Arabs. A lot of evidence has been found to prove the influence of Mesopotamia's religious beliefs on Arabs before Islam on the Arabian Peninsula. For example, in the religion of southern Arabs, the moon occupied the first position, and was symbolized in the form of an ox. Perhaps this is due to the fact that the ox has two horns that resemble the crescent, and the people of Yemen presented the moon on the sun as did the Babylonians and Chaldeans before them (Khan 1937: 110).

2 Carl Gustaf Jung, a Swiss psychologist and founder of Analytical Psychology. Lived July 26, 1875 June 6, 1961. He was an assistant physician at the Burgholzli psychiatric hospital in Zurich, and he became a theoretician of Freud's psychoanalytic theory.

3 Herodotus was a Greek historian who lived in the 5th century BC (about 484 BC - 425 BC). He is best known for his descriptions of several places he visited around the then known world, and he is the first Greek in history to name Palestine on the historical region of Palestine, and that was in the 6th century BC. 
As for the Arabs before Islam, they had the lunar god 'Sin' who possesses the first place in the triple group (the moon, the sun, and Ishtar). Considering that the moon god is the father of the sun god, and he used to symbolize the god (Sin) with a crescent, the god 'Shamash' is less than the moon god, while the gods Ashtar occupied the last rank, and he represented Venus (Kremer 1973: 158).

As for the worship of paganism on the Arabian Peninsula, it was a traditional image similar to the Babylonian paganism, and evidence of the influence of the Arabs in his country and Assyria. According to Salman (2015) they presented nights over the days because their months were based on the path of the moon, and they are bound by its movements, which is consistent with the view of the Chaldeans and Assyria, and that view differs from the belief of the Romans and Persians. One of the manifestations of the Arabs being affected by the idolatry of the Chaldeans and Assyria is that the word idol originates from 'salam', according to the Hebrew or Aramaic term (Salm). This word entered the peninsula together with the idols (Salman 2015: 197-207). It is known that the Arabs did not sculpt idols, due to their ignorance and lack of knowledge of sculptures, so it is believed that they were brought to them from abroad, including Hubble, and he is Baal, and Lat which is the Babylonian 'Lato', and (Manna) which is the Babylonian 'Mamnato', the daughter of the god, as they brought pride and is the 'Babylonian Ishtar' of their religion (Suleiman 1992: 253).

Dr. Farhat (2017) pointed out that "before the Islam, the Arabs had multiple gods, and the ancient Arab gods were monuments and idols spread at the time in the Mesopotamian civilization. Each fetish had a story, a myth, and a myth that narrowed its space and expanded according to the dimension of imagination among a number of people of discernment and know-how" (Farhat 2017: 7).

In his book "The History of Islamic Peoples", German historian Karl Brückelmann emphasized that "before Islam, the Arabs believed, like other Semitic peoples, that nature around them was loaded with powers greater than human powers. Indeed, the Semites considered trees, caves, springs, and stones." The symptoms in particular are inhabited by souls. From here the ancient Arabs sanctified a form of stone, in addition to all these gods. The Arabs, like other peoples in the Mesopotamia Valley, believed in a god who is the creator of the universe. This god is 'Allah' who did not transmit the Arabs' idea of the Jews and Christians, as many researchers think. There is no doubt that the Arabs were at first practicing religious rituals to those deities that were closer to them than Allah, the Lord of the Great Worlds (Brockelmann 1968: 64).

This confirms what the people of the news brought in their books. They found in it an explicit and clear recognition of the existence of a god they believed in, as they had called and fulfilled his name by saying: "To God be with you, to yours, there is no partner for you, except a partner who is yours, you own it and what you own. The machines with and around him and the vows with which they were closest to him all belong to God Almighty" (Ali 2001: 104).

The poetry of pre-Islamic Arabs clearly demonstrates that there is a belief in the worship of Allah, fear of him, drawing closer to him, and offering respect and appreciation of him: 


\section{And had it not been for the fear of Allah and the covenant******* he would have seen his father's wish from me the nights (Al-Asfahani 1956: 62).}

Likewise, the poetry of Zuhair bin Abi Salma claims that Allah is all-knowing, and possesses knowledge, secrets and mysteries, in appearance and inside

\section{Allah does not hold back what is in your souls to be hidden******* and whatever God knows is hidden (Suleiman 1944: 78).}

In the midst of these beliefs, an intellectual trend called 'eternity' emerged, and this belief was adopted by a group of people on the Arabian Peninsula, who were attributing events to eternity and attributing everything to the action of the laws of natural phenomena, that is, eternity, and its effect on human life. The eternity according to their belief is an uncreated and infinite concept, and in that they believed in old age and the non-annihilation of matter. Also, they believed that the world was administered by virtue of the astronomical movements, as they attributed death to the passage of time, which they saw as the first and last reason for existence. However, 'the eternal religion' was unable to stand in a line opposed to the prevailing paganism and Judaism and Christianity and the perception of one God who was represented by the Hanafi movement, and its spread remained limited (Saeed 2007: 80).

Frankfurt and his colleagues (1960) said in their book, "that the Arab person before Islam was if he wanted to understand nature, i.e. understand the many phenomena, he understood the personalities inherent in those phenomena. This led to the multiplicity of their ideas and beliefs and what they were believe in him from their worship of natural phenomena, living beings and stone even though they did not deny Allah but rather acknowledge his existence and condemn him. These beliefs are taken from the knowledge of the Babylonian man who was driven by his intuition to apply to nature his experience of human society, to communicate it to subsequent societies" (Frankfurt 1960: 16).

Before Islam, the Arabs were affected by the natural phenomena inherent in the desert environment. This is what helped them to follow the customs and traditions that they acquired from their predecessors in ancient civilizations, especially the Mesopotamian civilizations. Also, that belief led them to imagine the existence of hidden creatures that have a role in the events of changing the course of their lives, so they tried to seek and appease them with rituals and acts of worship and woven legends and myths similar to those in ancient civilizations in Mesopotamia. Their intellectual legacy remained firmly in the collective unconscious of all the tribes, and this is evident in their poetry. Poetry among the Arabs before Islam at that time was rooted in the belief systems of pre-Islamic life, so it provided them with a stock of religious and ritual concepts. This is, for example, evident in the poetry of Zaid bin Amr bin Nafil:

One God or a thousand God****** I will be condemned if things are divided Lat and Singles are all isolated as well ${ }^{* * * * * *}$ so does patient skin

(Nusrat 1982: 110). 
The remnants of the myths of creation, myths of jinn, ghouls, and planetary and pagan myths that defined the Mesopotamian civilizations, confirm the coexistence of these myths and legendary beliefs alongside religious thought among Arabs before Islam in different tribes and regions. Also, the belief in the existence of Allah Almighty and the practice of some Islamic rituals was present with them, but its orientation towards idolatry was evidenced by the statement made by the poet Zuhair bin Abi Salma in his comment:

\section{So I swore to the house that some of the men roamed around Quraish and dragged around}

Turn right to the two lords, and you will find them in every way

(Bin Al-Khatim 1967: 111).

\section{Conclusions}

This paper investigated the beliefs and ideas related to ancient religions that left their mark in the memory of history. It also examined the important factors that played a big role on the religions of pre-Islamic Arabs. Searching for the most important effects of the civilizations of the Mesopotamian valley on pre-Islamic Arabs provides some features and common characteristics between various periods. Finally, we can establish a chronology of the advancement of human civilizations in all fields, the most important of which is religion, so that we know why we have reached what we have today.

Therefore, the religious beliefs and rituals of ancient civilizations and Arab civilization before Islam have been the focus of attention and study of many historians and scholars. In our current paper, we talked about the religious ideology of some of the most famous civilizations known to man, the most important of which are the religions in the civilizations of the Mesopotamia and the pre-Islamic Arab civilization.

The article summarizes the most important results reached through the followings:

1. The religions of the Arabs before Islam are mainly derived from the texts of the ancient civilizations in the Mesopotamia valley (Babylonian, Assyrian, Sumerian, Akkadian, etc.) with their multiple dialects. They are texts among which there is no single text agreed upon in various religious matters, in order to vary the characteristics of those civilizations in terms of religious belief and devotion.

2. Before Islam, the Arabs worshiped the idols and monuments that they inherited from ancient civilizations. These idols were distinguished in various forms, including those in the form of humans, animals, or birds. Some of its most famous names are: Wad, Sawa, Yaghut, Yaqoub, Nisra, Al-Latt and Al-Ezzah, Minah, Hubble ... etc. 
3. The religious beliefs and practices of the Mesopotamian civilizations (the Sumerians, the Eastern Semitic Acadians, the Assyrians, the Babylonians, the Arameans, and the Chaldeans) were characterized by multiple religions, as the people were then worshiping and believing in more than one deity.

4. It was believed that the religions of Mesopotamia had a great influence on subsequent religions of all times for all parts of the world. Historical studies indicate that the religion of idols can be counted as the first religion practiced in the Mesopotamia valley; it was distinguished as a polytheistic religion.

5. Despite the multiple divinities in the Mesopotamia valley, and with the complexity of the economic, social, political and religious life at that time, laws and regulations had developed to regulate the existing relationships between people and for administrative and political dealings between peoples and their rulers. This confirms historical studies that the Mesopotamian civilization gained an advanced position in history.

6. The pre-Islamic region of Arabia witnessed the prevalence of various and varied religious beliefs, most of which were an extension of the ideas of ancient primitive civilizations, especially the Mesopotamian civilization, while the others were related to the rule of neighboring tribes of other peoples.

7. Before Islam, the Arabs used to worship any god they believed to be a descendant of their ancestors. Therefore, they owe him loyalty and make him a symbol for them, so they give him all respect, submission and appreciation.

8. What the Arabs achieved prior to Islam from practicing religious beliefs proves that the Arab nation from the era of the birth of ancient civilizations, especially the Mesopotamian civilization, has not been historically interrupted in the research and association with the first civilizational origins in the island, which was the center from which migrations to the Mesopotamian valley and the Nile valley originated.

9. The pre-Islamic region of Arabia witnessed the prevalence of various and varied religious beliefs, most of which were an extension of the ideas of ancient primitive civilizations, especially the Mesopotamian civilization.

10. The religions of Mesopotamia are among the most influential religions on the religious beliefs of Arabs before Islam, as we find a lot of evidence and evidence that proves the influence of Mesopotamian religious beliefs on Arabs before Islam on the Arabian Peninsula, for example, the moon dominated the religion of southern Arabs first. 
Address:

Hadeel Ghaleb Abbas

Department of History

Faculty of Education Ibn Rushd for Humanity

University of Baghdad

Baghdad, Iraq

E-mail: hadeel.abbbas@ircoeduiuobaghdad.edu.iq

Tel.: +9647725888303

\section{References}

Ajinah, Muhammad (2005) "On ignorance and its significance". Encyclopedia of Arab Myths. On Part 1. Beirut, Lebanon: Dar Al-Farabi

Akef, Adnan (2009) “Were old Iraqis amateurs of violence and blood?". Civilized Dialogue 2701. Baghdad, Iraq

Al-Asfahani, Ali bin Al-Hussein Abu Al-Faraj (1956) Songbook. Inquiry, presentation and supervision: Kazem Al-Mudhafar. Part 6. 2nd ed. Najaf Al-Ashraf, Iraq: Al-Haidariya Library Publications. Al-Asfahani, Ali bin Al-Hussein Abu Al-Faraj (1956) Songbook. Inquiry, presentation and supervision: Kazem Al-Mudhafar. Part 10. 2nd ed. Najaf Al-Ashraf, Iraq: Al-Haidariya Library Publications. Ali, Jawad (2001) A detailed history of the Arabs before Islam. Baghdad, Iraq: Dar al-Saqi.

Al-Saqri, Awatef Ibrahim (2014) "Effectiveness in the thinking of Malik bin Nabi and its relationship to culture and civilization". Kuwaiti Educational Journal 28, 110, 1-45.

Al-Sayeh, Ahmad Abdul-Rahim (1977) Islamic civilization. Part 1. 10th ed. Medina, Saudi Arabia: Islamic University of Madinah.

Badawi, Ammar (2005) The foundations of civilization and its demise factors from the perspective of the Noble Qur'an. Gaza, Palestine: An-Najah National University, Palestine.

Baqer, Taha (2011) An Introduction to the history of ancient civilizations. Part 2. Beirut, Lebanon: Dar Al-Warraq.

Baqer, Taha (2011) An introduction to the history of ancient civilizations, publisher: Dar Al-Warraq for Publishing and Distribution, first edition, first part, Beirut, Lebanon, p. (65).

Bin Al-Hassan, Badran (2015) "The civilization role of religion: an analytical study of the concept and role of complex religious idea by Ibn Malik". Journal of Literary and Intellectual Studies Generation (Center for Research and Studies Giza) 206, 2560, 1-14.

Bin Al-Khatim, Qais (1967) Diwan Qais bin Al-Khatim, investigation: Nasser Al-Din Al-Assad. 2nd ed. Beirut, Lebanon: Dar Sader Printing.

Brockelmann, Carl (1968) The history of Islamic peoples. Beirut, Lebanon: Dar Al-Alam for Millions.

Farhat, Ahmad (2017) "The Arabs of the Jahiliya were civilized, human, cultural and urban". Al Ittihad Newspaper (Beirut, Lebanon) 6626, 7.

Frankfurt, Henry, et al. (1960) Pre-Philosophy. Transl. by Jabra Ibrahim Jabra. Baghdad, Iraq: Dar Al-Hayat Library.

Habib, Kazem (2012) "Gates to enter Christianity in Mesopotamia". Civilized Dialogue (Baghdad, Iraq) 5422,8 .

Hassan, Zajia Abdul-Razzaq (2008) "Arab worship of the Moon before Islam". Literature of Basra (Basra, Iraq) 16, 46, 154-202. 
Herodotus, Halicarnassius (2001) The history of Herodotus. Transl. by Abd al-Ilah al-Mallah. 2nd ed. Dubai, United Arab Emirates: Abu Dhabi Cultural Foundation.

Jaafar, Ali Sadad (2017) "Apple and the Torah (the Torah and the Babylonian Torah), Babylonian religious thought". Journal of Al-Hilla Encyclopedia (Babylon, Iraq) 8, 10.

Jung C. G. (1988) Religion in the light of psychology. Transl. by Nihad Khayata. Damascus, Syria: Dar Aladdin Publishing.

Khan, Muhammad Abd al-Mu`id (1937) Pre-Islamic Arabic myths. Cairo: Tune Press.

Kharroub, Tayseer (2005) "The evolution of religious life among Arabs before Islam". Civilized Dialogue (Baghdad, Iraq) 1080.

Kovalev, Diakov (2000) Ancient civilizations. Tranls. by Naseem and Hakim Al-Yaziji. Damascus, Syria: Dar Aladdin.

Kremer, Samuel Noah (1973) The Sumerians, their history, civilization and characteristics. Kuwait: Publications Agency for Publishing and Distribution.

Muhammad, Fadel Zaki (1970) Arab political thought between its past and present. Baghdad, Iraq: Dar Al-Ahlya.

Nusrat, Abd al-Rahman (1982) The artistic image in pre-Islamic poetry in the light of modern criticism. 2nd ed. Amman, Jordan: Al-Aqsa Library.

Parpola, Simo (2004) "National and ethnic identity in the Neo-Assyrian Empire and Assyrian identity in Post-Empire times". Journal of Assyrian Academic Studies 18, 2.

Rashid, Abdel-Wahab Hamid (2012) "Mesopotamia civilization". Mesopotamia 9 - religious belief .. social life .. philosophical ideas. Civilized dialogue (Baghdad, Iraq) 3872.

Sachs, Henry (1969) The power of Assyria. Transl. by D. Amer Suleiman. Mosul, Iraq: Ministry of Higher Education and Scientific Research.

Saeed, Louay Mahmoud (2007) Idol tightness ... the popular concept of divine protection in ancient Egypt. PhD thesis, Faculty of Archeology, Cairo University. Cairo, Egypt.

Saeed, Muayyad (1985) "Architecture from the era of the dawn of dynasties to the end of the modern Babylonian era". The civilization of Iraq. Part 3. Baghdad, Iraq: Freedom House.

Salman, Yildiz Dawood (2015) "A comparison between the religious beliefs of Mesopotamia and preIslamic Arabs (comparative historical study)". Journal of the Babylon Center for Humanities $5,1,197-207$.

Sarton, George (1955) "Chaldaean astronomy of the last three centuries B.C.". Journal of the American Oriental Society 75.3: 166-173. Doi:10.2307/595168.

Schweitzer, Albert (1963) The philosophy of civilization. Transl. by Dr. Zaki Naguib Mahmoud. Cairo: General Book Authority.

Suleiman, Abi Al-Hajjaj Yousef Ibn (1944) The syntactic literature. Cairo: Dar Al-Kutub Al-Masria. Suleiman, Amer (1992) Iraq in ancient history. Mosul: Dar Al-Kutub. 